\title{
POSITIVE SOLUTIONS FOR A SINGULAR COUPLED SYSTEM OF NONLINEAR HIGHER-ORDER FRACTIONAL $q$-DIFFERENCE BOUNDARY VALUE PROBLEMS WITH TWO PARAMETERS
}

\author{
WENGUI YANG
}

Abstract. In this paper, we are concern with the existence of positive solutions for a singular system of nonlinear fractional $q$-difference equations with coupled integral boundary conditions and two parameters. By using the properties of the Green's function and Guo-Krasnosel'skii fixed point theorem, some existence results of at least one positive solution are obtained. As applications, two examples are presented to illustrate the main results.

Mathematics subject classification (2010): 39A13, 34B18, 34A08.

Keywords and phrases: Fractional $q$-difference systems, coupled integral boundary conditions, positive solution, Green's function, fixed point theorems.

\section{REFERENCES}

[1] T. Abdeljawad and J. Alzabut, The q-fractional analogue for Gronwall-type inequality, J. Funct. Spaces Appl., 2013, (2013), Art. ID 543839, 1-7.

[2] T. Abdeljawad, J. Alzabut And D. Baleanu, A generalized q-fractional Gronwall inequality and its applications to nonlinear delay q-fractional difference systems, J. Inequal. Appl., 2016 (2016), no. 240, 1-13.

[3] B. AHMAD ET AL., Existence and uniqueness results for a nonlocal q-fractional integral boundary value problem of sequential orders, J. Comput. Anal. Appl., 20 (2016), 514-529.

[4] B. Ahmad, J. J. Nieto, A. Als Aedi AND H. Al-Hutami, Existence of solutions for nonlinear fractional q-difference integral equations with two fractional orders and nonlocal four-point boundary conditions, J. Franklin Inst., 351 (2014), 2890-2909.

[5] B. Ahmad, S. K. NTOUYAS AND I. K. PuRnaras, Existence results for nonlocal boundary value problems of nonlinear fractional q-difference equations, Adv. Differ. Equ., 2012 (2012), no. 140, $1-15$.

[6] M. H. Annaby And Z. S. Mansour, q-Fractional calculus and equations, Lect. Notes Math., vol. 2056, Springer, Berlin, 2012.

[7] R. A. C. FERreira, Positive solutions for a class of boundary value problems with fractional $q$ difference, Comput. Math. Appl., 61 (2011), 367-373.

[8] R. A. C. FERREIRA, Nontrivial solutions for fractional q-difference boundary value problems, Electron, J. Qual. Theory Differ. Equ., 2010 (2010), no. 70, 1-10.

[9] C. S. GOODRICH, Existence of a positive solution to systems of differential equations of fractional order, Comput. Math. Appl., 62 (2011), 1251-1268.

[10] J. R. GRAEF AND L. KONG, Positive solutions for a class of higher order boundary value problems with fractional q-derivatives, Appl. Math. Comput., 218 (2012), 9682-9689.

[11] J. R. GRAEF, L. Kong, Q. Kong AND M. WANG, Uniqueness and parameter dependence of positive solutions to higher order boundary value problems with fractional q-derivatives, J. Appl. Anal. Comput., 3 (1) (2013), 21-35.

[12] D. J. Guo and V. Lakshmikantham, Nonlinear problems in abstract cones, Academic Press, New York, 1988.

[13] J. HENDERSON AND R. LUCA, Existence and multiplicity of positive solutions for a system of fractional boundary value problems, Bound. Value Prob., 2014 (2014), no. 60, 1-17. 
[14] J. HENDERSON AND R. LUCA, Positive solutions for a system of fractional differential equations with coupled integral boundary conditions, Appl. Math. Comput., 249 (2014), 182-197.

[15] J. HENDERSON AND R. LuCA, Boundary value problems for systems of differential, difference and fractional equations: Positive solutions, Elsevier, Amsterdam, 2016.

[16] J. Henderson, R. LuCA AND A. TudorACHE, On a system of fractional differential equations with coupled integral boundary conditions, Fract. Calc. Appl. Anal., 18 (2015), 361-386.

[17] V. KAC AND P. CHEUng, Quantum calculus, Springer, New York, NY, USA, 2002.

[18] A. A. Kilbas, H. M. SRIVAStava And J. J. TRujlllo, Theory and applications of frational differential equations, Elsevier, Boston, 2006.

[19] Y. LI AND W. YANG, Monotone iterative method for nonlinear fractional $q$-difference equations with integral boundary conditions, Adv. Differ. Equ., 2015 (2015), no. 294, 1-10.

[20] S. K. NTOUYAS AND J. TARIBOON, Fractional q-integrodifference equations and inclusions with nonlocal fractional q-integral conditions, J. Comput. Anal. Appl., 20 (2016), 647-665.

[21] S. K. Ntouyas, J. TARiboon And P. Thiramanus, Mixed problems of fractional coupled systems of Riemann-Liouville differential equations and Hadamard integral conditions, J. Comput. Anal. Appl., 21 (2016), 813-828.

[22] I. Podlubny, Fractional differential equations, Academic Press, New York, 1999.

[23] J. REN AND C. ZHAI, A fractional $q$-difference equation with integral boundary conditions and comparison theorem, Int. J. Nonlinear Sci. Numer. Simul., 18 (7-8) (2017), 575-583.

[24] Y. WANG, L. LIU AND Y. WU, Positive solutions for a class of higher-order singular semipositone fractional differential systems with coupled integral boundary conditions and parameters, Adv. Differ. Equ. 2014 (2014), no. 268, 1-24.

[25] S. XIE AND Y. XIE, Positive solutions of higher-order nonlinear fractional differential systems with nonlocal boundary conditions, J. Appl. Anal. Comput., 6 (4) (2016), 1211-1227.

[26] W. YANG, Positive solutions for a coupled system of nonlinear fractional differential equations with integral boundary conditions, Comput. Math. Appl., 63 (2012), 288-297.

[27] W. YANG, Positive solution for fractional $q$-difference boundary value problems with $\phi$-Laplacian operator, Bull. Malays. Math. Sci. Soc., 36 (4) (2013), 1195-1203.

[28] W. YANG, Positive solutions for boundary value problems involving nonlinear fractional q-difference equations, Differ. Equ. Appl., 5 (2) (2013), 139-153.

[29] W. YANG, Positive solutions for nonlinear semipositone fractional q-difference system with coupled integral boundary conditions, Appl. Math. Comput., 244 (2014), 702-725.

[30] W. YANG, Positive solutions for singular coupled integral boundary value problems of nonlinear Hadamard fractional differential equations, J. Nonlinear Sci. Appl., 8 (2) (2015), 110-129.

[31] W. YANG, Positive solutions for singular Hadamard fractional differential system with four-point coupled boundary conditions, J. Appl. Math. Comput., 49 (2015), 357-381.

[32] W. Yang, A. Alsaedi, T. Hayat And H. M. Fardoun, Asymptotical stability analysis of Riemann-Liouville $q$-fractional neutral systems with mixed delays, Math. Meth. Appl. Sci., 2019, in press, doi: https://doi.org/10.1002/mma.5700

[33] W. YANG AND Y. QIN, Positive solutions for nonlinear Caputo type fractional q-difference equations with integral boundary conditions, Mathematics, 4 (4) (2016), no. 63, 1-15.

[34] C. YUAN, Two positive solutions for $(n-1,1)$-type semipositone integral boundary value problems for coupled systems of nonlinear fractional differential equations, Commun. Nonlinear Sci. Numer. Simul., 17 (2012), 930-942.

[35] C. YuAn, D. JiAng, D. O'Regan And R. P. AgARwal, Multiple positive solutions to systems of nonlinear semipositone fractional differential equations with coupled boundary conditions, Electron. J. Qual. Theory Differ. Equ., 2012 (2012), no. 13, 1-17.

[36] Q. YUAN AND W. YANG, Positive solutions of nonlinear boundary value problems for delayed fractional q-difference systems, Adv. Differ. Equ., 2014 (2014), no. 51, 1-16.

[37] Q. YUAN AND W. YANG, Positive solution for q-fractional four-point boundary value problems with p-Laplacian operator, J. Inequl. Appl., 2014 (2014), no. 481, 1-14.

[38] C. ZHAI AND J. REN, The unique solution for a fractional $q$-difference equation with three-point boundary conditions, Indagat. Math., 29 (3) (2018), 948-961.

[39] Q. ZHAO AND W. YANG, Positive solutions for singular coupled integral boundary value problems of nonlinear higher-order fractional q-difference equations, Adv. Differ. Equ., 2015 (2015), no. 290, 1-22. 
[40] W. ZHOU ANF H. LIU, Uniqueness and existence of solution for a system of fractional q-difference equations, Abstr. Appl. Anal., 2014 (2014), Art. ID 340159, 1-11. 